\title{
Synthesis, Crystal Structure, Antioxidant Activity, and DNA-Binding Studies of a Novel Ni(II) [2×2] Grid Complex with a Rigid Bistridentate Schiff Base Ligand
}

\author{
Lei JIA,${ }^{a, b}$ Jun Xu, ${ }^{a}$ Xi-Ming Xu,,${ }^{c}$ Long-Hai Chen,,${ }^{a}$ Peng JiAng,,${ }^{c}$ Fei-Xiang Cheng, ${ }^{a}$ \\ Guang-Nong LU, ${ }^{a}$ Qin WANG, ${ }^{*, c}$ Jin-Cai Wu, ${ }^{a}$ and Ning TANG ${ }^{*}, a$ \\ ${ }^{a}$ Key Laboratory of Nonferrous Metal Chemistry and Resources Utilization of Gansu Province, State Key Laboratory of \\ Applied Organic Chemistry, College of Chemistry and Chemical Engineering, Lanzhou University; ' School of Life \\ Science, Lanzhou University; Lanzhou 730000, P.R. China: and ${ }^{b}$ Department of Physics and Chemistry, Henan \\ Polytechnic University; Jiaozuo 454000, P. R. China.
}

Received September 29, 2009; accepted May 12, 2010; published online May 13, 2010

With a bistridentate Schiff-base ligand, $N^{\prime}, N^{\prime 3}$-bis[(1E)-1-(2-pyridinyl)ethylidene)] isophthalohydrazide $\left(\mathrm{H}_{2} \mathrm{~L}\right)$, a $[2 \times 2] \mathrm{G}$ grid complex, $\left[\mathrm{Ni}_{4}(\mathrm{HL})_{4}\right]\left(\mathrm{ClO}_{4}\right)_{4} \cdot 4 \mathrm{H}_{2} \mathrm{O} \cdot 0.5 \mathrm{CH}_{3} \mathrm{OH}(1)$ has been synthesized and characterized spectroscopically and crystallographically. Spectrometric titrations, ethidium bromide displacement experiments, circular dichroism spectral analysis and viscosity measurements indicate that the compound 1 strongly binds with calf-thymus DNA, presumably via intercalation mechanism. Furthermore, the antioxidant activity (superoxide and hydroxyl radical) of the ligand and its nickel(II) complex is determined by using spectrophotometer methods in vitro. Complex 1 is found to possess potent antioxidant activity and be better than standard antioxidants like mannitol.

Key words crystal structure; Ni(II) complex; intercalation binding; antioxidant activity

It is well known that deoxyribonucleic acid (DNA) plays an important role in the life process since it contains all the genetic information for cellular function. ${ }^{1)}$ Investigations of the interactions of DNA with transition metal complexes are basis to design new types of the pharmaceutical molecules to elucidate the mechanism involved in the site specific recognition of DNA and to determine the principles governing the recognition. ${ }^{2,3)}$ Schiff bases exhibit remarkable biological activity and play an important role in bioinorganic chemistry. For example, the $\mathrm{Cr}$ (III) complexes can lead to DNA damage, plasmid cleavage, and protein cleavage. ${ }^{4,5)}$ The acid hydrazides possess $\mathrm{R}-\mathrm{CO}-\mathrm{NH}-\mathrm{NH}_{2}$, a class of Schiff base, their corresponding aroylhydrazones, $\mathrm{R}-\mathrm{CO}-\mathrm{NH}-\mathrm{N}=\mathrm{CH}-$ $\mathrm{R}^{\prime}$, and the dependence of their mode of chelation with transition metal ions present in the living system have been of significant interest. ${ }^{\text {) }}$ Various coordination compounds of aroylhydrazones have been reported to act as enzyme inhibitors and are useful due to their pharmacological applications. $^{7-9)}$

Nickel is recognized as an essential trace element for bacteria, plants, animals, and humans, though the role of this metal in animal biochemistry is still not well defined. ${ }^{10)}$ These facts encouraged us to synthesize a novel ligand $N^{\prime}, N^{\prime 3}$-bis[(1E)-1-(2-pyridinyl)ethylidene)] isophthalohydrazide $\left(\mathrm{H}_{2} \mathrm{~L}\right.$, Fig. 1) and their $\mathrm{Ni}(\mathrm{II})$ complex. In addition, the DNA-binding properties of the complex $\left[\mathrm{Ni}_{4}(\mathrm{HL})_{4}\right]$ $\left(\mathrm{ClO}_{4}\right)_{4} \cdot 4 \mathrm{H}_{2} \mathrm{O} \cdot 0.5 \mathrm{CH}_{3} \mathrm{OH}(\mathbf{1})$ was discussed in detail.

\section{Results and Discussion}

Synthesis and General Properties Complex 1 was prepared in high yield from reactions of the Schiff base ligand $\mathrm{H}_{2} \mathrm{~L}$ in the presence of $\mathrm{Ni}\left(\mathrm{ClO}_{4}\right)_{2} \cdot 6 \mathrm{H}_{2} \mathrm{O}$. The UV-Vis investigations revealed that the spectra of the $\mathrm{Ni}(\mathrm{II})$ complex in $\mathrm{N}, \mathrm{N}$-dimethylformamide (DMF) solution have remained unaltered for the solutions and its molar conductance values have no obvious change for very freshly prepared and for

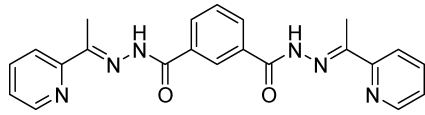

Fig. 1. The Structure of $\mathrm{H}_{2} \mathrm{~L}$

over the whole experiment $(24 \mathrm{~h})$. It indicated that the $\mathrm{Ni}(\mathrm{II})$ complex is quite stable in solution. The molar conductivity data is in accordance with the 1:4 type electrolyte.

Crystal Structure The crystal and experimental data is presented in Table 1. The selected bond distances and angles are presented in Table 2. Single-crystal X-ray analyses revealed that complex 1 crystallized in the space group $I 4 / \mathrm{m}$ consisting of the cationic square, $\left[\mathrm{Ni}_{4} \mathrm{H}_{4} \mathrm{~L}_{4}\right]^{4+}$. As shown in Fig. 2, in which the ligand $\mathrm{H}_{2} \mathrm{~L}$ coordinates to metal ion, it becomes negatively charged, $\mathrm{HL}^{-}$, and the ligands were divided into pairs, one of which lies above and the other below the mean plane through the four metal ions, giving a novel $[2 \times 2]$ grids. The four $\mathrm{Ni}(\mathrm{II})$ atoms are distorted octahedral coordinated by two acyloxy oxygen, two amide, and two pyridine $\mathrm{N}$ atoms, evidenced by the angles $\mathrm{O} 1-\mathrm{Ni} 1-\mathrm{N} 1$ $\left(154.3(2)^{\circ}\right)$ and $\mathrm{O} 1-\mathrm{Ni} 1-\mathrm{N} 2 \quad\left(76.8(2)^{\circ}\right)$. The distortion mainly originates from the extremely rigid binding pockets present within each ligand, with two coplanar five-membered chelate rings formed upon complexation, including one to the smaller-sized pyrazolate heterocycle, and the resulting proximity of the parallel ligand strands in the very compact grid array. So, four $\mathrm{Ni}(\mathrm{II})$ atoms occupy the corners of a $[2 \times 2]$ grid with edge lengths $\mathrm{Ni} \cdots \mathrm{Ni} 8.486 \AA$. The metal-metal diagonal distances are $11.465 \AA$ for $\mathbf{1}$. The grids are not perfectly square as can be seen by the dihedral angle between the two chelating planes around each $\mathrm{Ni}(\mathrm{II})$ center ranges from 87.01 to $92.69 \AA$ for $\mathbf{1}$. The ligand molecules on opposite sides of the grids are also inclined to one another. This is shown by the dihedral angles involving the opposing benzene rings, $9.14^{\circ}$ for 1 . Distances between some of the 
Table 1. Crystal and Experimental Data

\begin{tabular}{ll}
\hline \hline Empirical formula & $\mathrm{C}_{88.50} \mathrm{H}_{86} \mathrm{Cl}_{4} \mathrm{~N}_{24} \mathrm{Ni}_{4} \mathrm{O}_{28.50}$ \\
Formula weight & 2318.47 \\
Temperature & $223(2) \mathrm{K}$ \\
Wavelength & $0.71073 \AA$ \\
Crystal system & Tetragonal \\
Space group & $I 4 / m$ \\
Unit cell dimensions $\left(\AA,^{\circ}\right)$ & \\
$a$ & $22.1357(5)$ \\
$b$ & $22.1357(5)$ \\
$c$ & $26.6683(12)$ \\
$\beta$ & 90 \\
Volume $\left(\AA^{3}\right)$ & $13067.2(7)$ \\
$Z$ & 4 \\
$D$ calcd $\left(\mathrm{g} / \mathrm{cm}^{3}\right)$ & 1.137 \\
Absorption coefficient $\left(\mathrm{mm}^{-1}\right)$ & 0.676 \\
$F(000)$ & 4596 \\
Range of $h k l$ & $-25 / 26,-26 / 24,-31 / 31$ \\
Reflections collected & 36384 \\
Data/restraints/parameters & $5659 / 37 / 393$ \\
Independent reflections & 5659 \\
Max. and min. transmission & $0.9354,0.6137$ \\
Goodness-of-fit on $F^{2}$ & 0.980 \\
Final $R$ indices $[I>2 \sigma(I)]$ & $R 1=0.0742, w R 2=0.1139$ \\
Largest diff. peak and hole & $0.530,-0.383$ \\
&
\end{tabular}

Table 2. Selected Bond Distance and Angle $\left(\AA,^{\circ}\right)$

\begin{tabular}{lclc}
\hline \hline $\mathrm{Ni}(1)-\mathrm{N}(5)^{a}$ & $1.979(6)$ & $\mathrm{N}(5)-\mathrm{Ni}(1)^{b)}$ & $1.979(6)$ \\
$\mathrm{Ni}(1)-\mathrm{N}(2)$ & $1.981(6)$ & $\mathrm{N}(4)-\mathrm{Ni}(1)^{b)}$ & $2.108(5)$ \\
$\mathrm{Ni}(1)-\mathrm{N}(4)^{a)}$ & $2.108(5)$ & $\mathrm{Ni}(1)-\mathrm{N}(1)$ & $2.103(6)$ \\
$\mathrm{O}(2)-\mathrm{Ni}(1)^{b)}$ & $2.067(4)$ & $\mathrm{O}(2)-\mathrm{Ni}(1)^{b)}$ & $2.067(4)$ \\
$\left.\mathrm{N}(5)^{a}\right)-\mathrm{Ni}(1)-\mathrm{N}(2)$ & $176.4(2)$ & $\left.\mathrm{O}(2)^{a}\right)-\mathrm{Ni}(1)-\mathrm{N}(1)$ & $89.2(2)$ \\
$\mathrm{N}(5)^{a}-\mathrm{Ni}(1)-\mathrm{O}(2)^{a)}$ & $77.6(2)$ & $\mathrm{O}(1)-\mathrm{Ni}(1)-\mathrm{N}(1)$ & $154.3(2)$ \\
$\mathrm{N}(2)-\mathrm{Ni}(1)-\mathrm{O}(2)^{a)}$ & $105.7(2)$ & $\mathrm{N}(5)^{a)}-\mathrm{Ni}(1)-\mathrm{N}(4)^{a)}$ & $77.5(2)$ \\
$\mathrm{N}(5)^{a}-\mathrm{Ni}(1)-\mathrm{O}(1)$ & $104.6(2)$ & $\mathrm{N}(2)-\mathrm{Ni}(1)-\mathrm{N}(4)^{a)}$ & $99.2(2)$ \\
$\mathrm{N}(2)-\mathrm{Ni}(1)-\mathrm{O}(1)$ & $76.8(2)$ & $\mathrm{O}(2)^{a)}-\mathrm{Ni}(1)-\mathrm{N}(4)^{a)}$ & $155.0(2)$ \\
$\left.\mathrm{O}(2)^{a}\right)-\mathrm{Ni}(1)-\mathrm{O}(1)$ & $92.0(2)$ & $\mathrm{O}(1)-\mathrm{Ni}(1)-\mathrm{N}(4)^{a)}$ & $92.13(19)$ \\
$\mathrm{N}(5)^{a}-\mathrm{Ni}(1)-\mathrm{N}(1)$ & $100.8(2)$ & $\mathrm{N}(1)-\mathrm{Ni}(1)-\mathrm{N}(4)^{a}$ & $97.6(2)$ \\
$\mathrm{N}(2)-\mathrm{Ni}(1)-\mathrm{N}(1)$ & $78.1(2)$ & & \\
& & & \\
\hline
\end{tabular}

a) $-y+1 / 2, x-1 / 2,-z+1 / 2$.

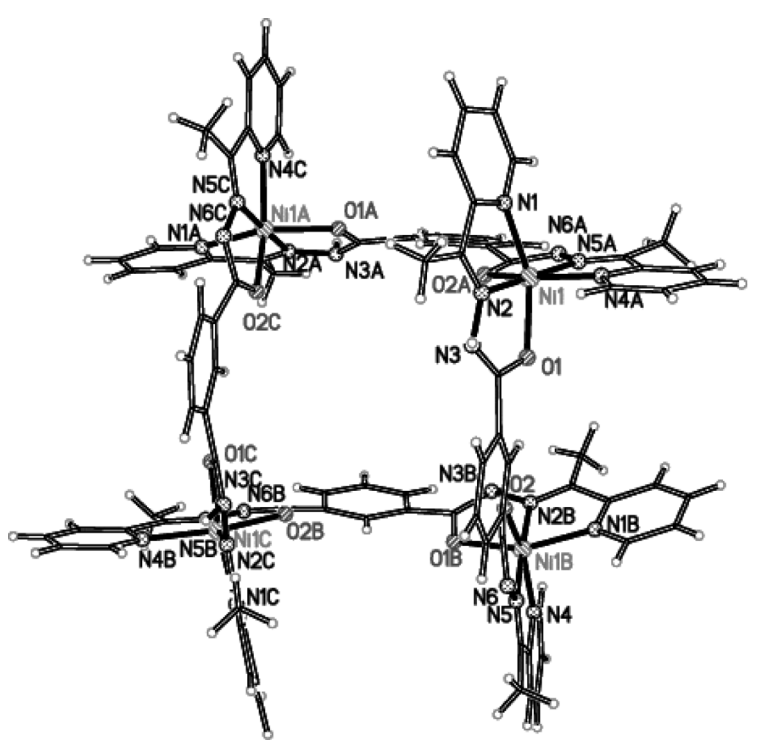

Fig. 2. Cationic Molecular Square of Complex 1

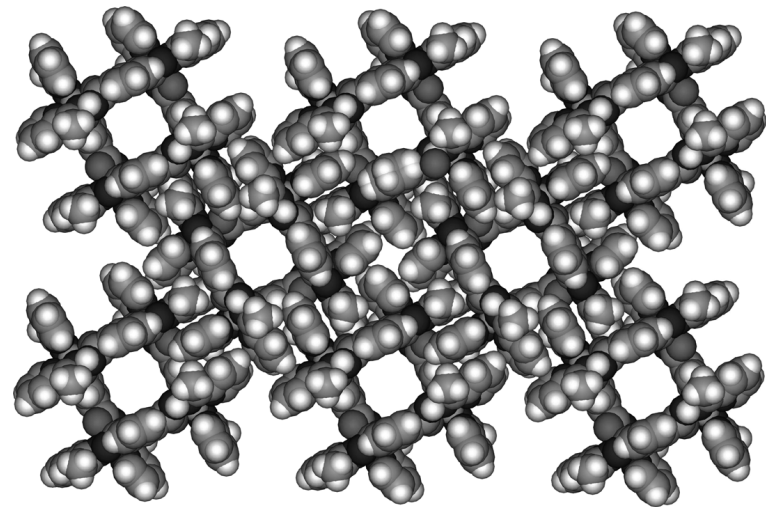

Fig. 3. Packing in the Cationic Lattice of $\mathbf{1}$ Shows the Tetragonal Channels

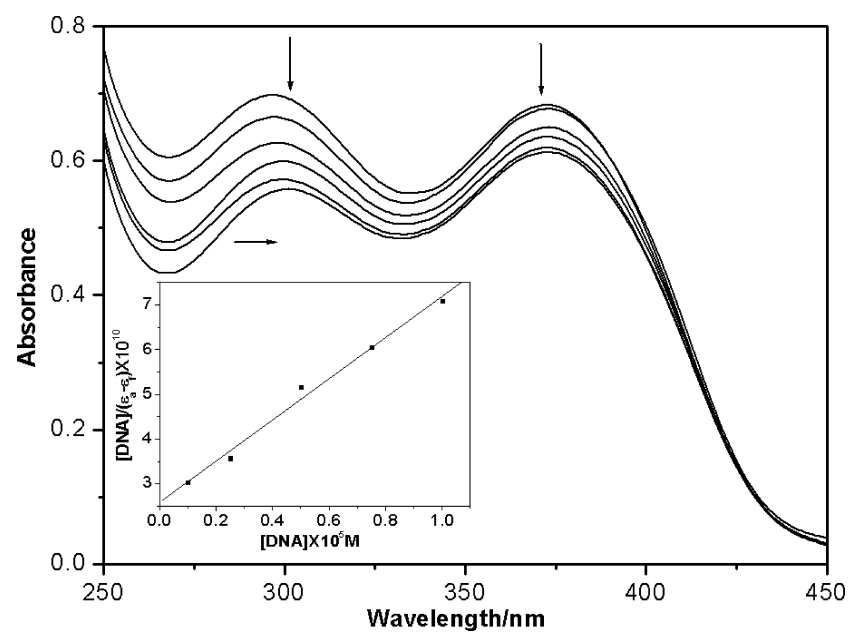

Fig. 4. Electronic Spectra of the Complex 1 in the Presence of $0-10 \mu \mathrm{l}$ $1.0 \times 10^{-4}$ M CT-DNA

Arrow shows the emission intensities changes upon increasing DNA concentration. Inset: plots of [DNA] $/\left(\varepsilon_{\mathrm{a}}-\varepsilon_{\mathrm{f}}\right) v s$. [DNA] for the titration of DNA to complex.

aromatic rings are around $3.574 \AA$, indicative of $\pi-\pi$ stacking. The aromatic rings alongside one ligand "plane" show some deviation from coplanarity, with dihedral angles between two pyridine rings of $9.15-21.79^{\circ}$. As shown in Fig. 3 , the cationic squares in $\mathbf{1}$ are stacked in a parallel and overlapping fashion along the $c$ direction to form large rhombic channels which are filled with solvent molecules.

DNA-Binding Studies The ligand has no effect on the absorption of DNA solutions. The absorption spectra of $\mathbf{1}$ in the absence and presence of calf-thymus DNA (CT-DNA) is given in Fig. 4. In the absence of CT-DNA, the UV-Vis absorption spectra of the complex 1 has strong $\pi-\pi^{*}$ transitions band at $\lambda_{\max }=296 \mathrm{~nm}$ and a strong $n-\pi^{*}$ transitions band at $\lambda_{\max }=372 \mathrm{~nm}$. With increasing DNA concentration, the absorption bands of the compound show decreases in molar absorptivity (hypochromism). Addition of DNA also leads to changes in the position of absorption bands. The $296 \mathrm{~nm}$ band is red shifted by $6 \mathrm{~nm}$ in the presence of DNA. These variations are strongly indicative of the intercalation mode of the compounds with CT-DNA, involving a strong $\pi$ stacking interaction between the compounds and DNA base pairs. ${ }^{11)}$ In order to study the binding ability of the compounds with DNA quantitatively, the binding constant $K_{\mathrm{b}}$ was 
determined using the equation in literature. ${ }^{12)}$ In plots of [DNA] $/\left(\varepsilon_{\mathrm{a}}-\varepsilon_{\mathrm{f}}\right)$ versus [DNA], $K_{\mathrm{b}}$ is given by the ratio of slope to the intercept. The binding constants $K_{\mathrm{b}}$ for $\mathbf{1}$ is found to be $1.84 \times 10^{6} \mathrm{M}^{-1}$. The $K_{\mathrm{b}}$ value obtained here is higher than the other mononuclear or dinuclear Ni(II) complexes reported before. ${ }^{13)}$

In order to further investigate the interaction mode between the complex 1 and CT-DNA, the fluorescence titration experiments are performed. The fluorescence intensity of ethidium bromide (EB) at $584 \mathrm{~nm}$ show a remarkable decreasing trend with the increasing concentration of the complex 1, indicating that some EB molecules are released from EB-DNA after an exchange with the complex 1 which results in the fluorescence quenching of EB. We assume it may be due to the metal complex competing with EB for the DNA binding sites thus displacing the EB, which implies that complex 1 binds more strongly to DNA than EB at $50 \mathrm{~mm}$ $\mathrm{NaCl}$ concentration. The quenching plots determined by literature illustrate that the quenching of EB bound to DNA by the complexes is in good agreement with the linear Stern-Volmer equation. ${ }^{14)}$ The $K_{\mathrm{q}}$ value of Ni(II) complex is $1.52 \times 10^{5} \mathrm{M}^{-1}$. This is in accordance with the above absorption titration result.

The circular dichroism (CD) spectrum of CT-DNA was monitored in the presence of $\mathbf{1}$. On addition of the complex $\mathbf{1}$ to CT-DNA, it shows faint red shift with intensity increase in the positive band. This observation is supportive of the intercalative mode of binding of the complex $\mathbf{1}$, where in the stacking of the complex molecules between the base pairs of DNA leads to an enhancement in the positive band and the partial unwinding of the helix is reflected in the decreased intensity of the negative band, which attributed to a strong conformational change in DNA helix. The results obtained here validate those obtained from the UV-Vis spectral studies.

The effects of the compounds together with EB on the viscosity of DNA at $25.0 \pm 0.1^{\circ} \mathrm{C}$ are investigated. It is found that the viscosity of DNA increases steadily with the increase of the concentration of the compound, which is similar to that of a classical intercalator EB. ${ }^{15)}$ This result demonstrates that the complex 1 and EB bind to DNA through the classical intercalation mode, which also parallels the pronounced hypochromism and spectral red shift of the complex in the absorption spectrum experiment.

Antioxidant Activity As can be seen in Fig. 5a, the inhibitory effect of the tested complexes on $\mathrm{O}_{2}^{-\cdot}$ is concentration related. The antioxidant activities of the complex and ligand are expressed as $50 \%$ inhibitory concentration $\left(\mathrm{IC}_{50}\right.$ in $\mu \mathrm{M}) . \mathrm{IC}_{50}$ values of $\mathbf{1}$ is $12.53 \pm 0.32 \mu \mathrm{M}$. The $\mathrm{IC}_{50}$ value of the ligand can not be read in Fig. 5a. It is clear that the scavenger effect on $\mathrm{O}_{2}^{-}$can be enhanced by the formation of metal-ligand coordination complexes and the nature of the metal ion also affects the ability. Some complexes are better effective inhibitor for $\mathrm{O}_{2}^{-\cdot}$ than that of the nitroxide Tempo $\left(\mathrm{IC}_{50}=60 \pm 3.10 \mu \mathrm{M}\right)$ which has been recently used in biological system for its capacity to mimic superoxide dismutase. ${ }^{16)}$ Although superoxide is a relatively weak oxidant, it decomposes to form stronger relative oxidative species, such as single oxygen and hydroxyl radicals, which initiate peroxidation of lipids. ${ }^{17)}$ These results show that complex 1 has significant scavenging activity of superoxide radical.

We can find that the complex and ligand scavenge $\mathrm{OH}$

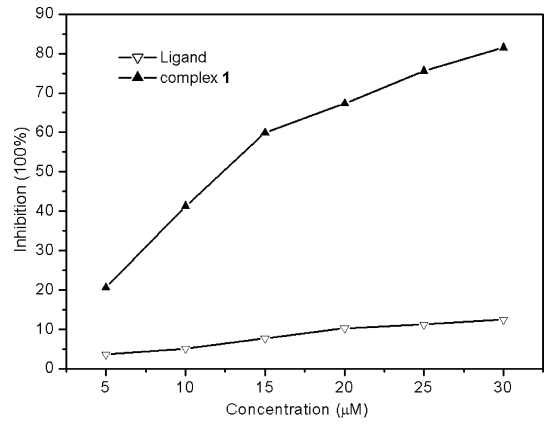

(a)

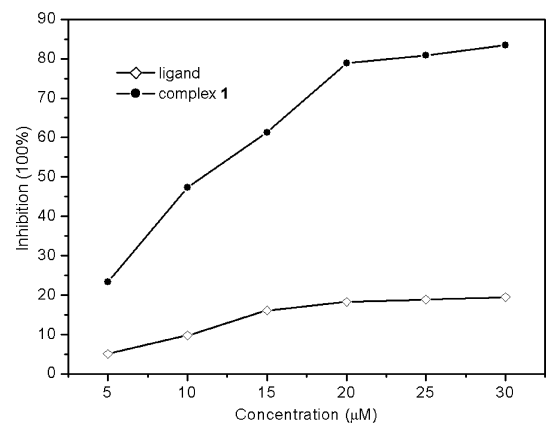

(b)

Fig. 5. (a) Effect of Tested Complex 1 and Ligand on $\mathrm{O}_{2}^{-}$, (b) Effect of Tested Complex 1 and Ligand on $\mathrm{OH}$

Experiments were performed in triplicate. Values are expressed as mean \pm standard deviation $(n=3)$

also in a concentration-dependent manner (Fig. 5b). The complex 1 shows highly active scavenging effect on $\mathrm{OH}$. Moreover, mannitol is a well-known natural antioxidant, so we also studied the scavenging activity of mannitol against hydroxyl radical using the same model. We find that when arrive at similar suppression ratio, concentration of complex $\mathbf{1}$ is far less than that of mannitol. The suppression ratio take the order of $1>\mathrm{H}_{2} \mathrm{~L}$. The metal complex we studied in this paper deserve to be further researched.

\section{Experimental}

Materials Nitroblue tetrazolium (NBT), methionine (MET), vitamin $\mathrm{B}_{2}$ $\left(\right.$ VitB $\left._{2}\right)$ were purchased from Sigma Chemical Co. Calf thymus DNA (CTDNA) and ethidium bromide (EB) were obtained from Sigma Chemical Co. All the experiments were carried out in doubly distilled water buffer containing $5 \mathrm{~mm}$ Tris[Tris(hydroxymethyl)-aminomethane] and $50 \mathrm{~mm} \mathrm{NaCl}$, and adjusted to $\mathrm{pH} 7.2$ with hydrochloric acid. The concentration of DNA solution was determined from UV absorption at $260 \mathrm{~nm}$ using a molar absorption coefficient $\varepsilon_{260}=6600 \mathrm{~mol}^{-1} \mathrm{~cm}^{-1}$.

Physical Measurements The UV-Vis absorption measurements were conducted by using a Varian Cary 100 spectrophotometer equipped with quartz cells. All fluorescence emission spectra were measured using a Hitachi F-4500 spectrofluorophotometer equipped with a xenon lamp source and a quartz cell of $1 \mathrm{~cm}$ path length. Viscosity experiments were carried out on an Ubbelodhe viscometer. The CD spectra were recorded on a Jasco J-810 spectropolarimeter. The elemental analyses were performed in the microanalytical laboratory, Department of Chemistry, National University of Singapore. The ${ }^{1}$ H-NMR spectra were recorded with a Bruker ACF300 FTNMR instrument using tetramethylsilane (TMS) as an internal reference in $\mathrm{D}_{2} \mathrm{O}$ for the ligand. Electrospray ionization (ESI) mass spectra were recorded on a Finnigan MAT LCQ mass spectrometer using the syringe pump method. All conductivity measurements were performed in $N, N^{\prime}$ dimethyl formamide (DMF) with a DDS-11A conductor at $25^{\circ} \mathrm{C}$. The antioxidant activites were tested on a $721 \mathrm{E}$ spectrophotometer (Shanghai 
Analytical Instrument Factory, China).

DNA Binding Experiment Methods Absorption titration experiments were performed by fixing concentration of $\mathbf{1}$ as constant at $10 \mu \mathrm{M}$ while varying the concentration of CT-DNA $\left(10^{-4} \mathrm{~mol} / \mathrm{l}\right)$. Fluorescence spectra of the competitive binding experiments were carried out by maintaining the EB and CT-DNA concentration at $3 \mu \mathrm{M}$ and $30 \mu \mathrm{M}$, respectively, while increasing the concentrations of the compound. Viscosity experiments were carried out on an Ubbelodhe viscometer, immersed in a thermostated water-bath maintained at $25.0 \pm 0.1^{\circ} \mathrm{C}$. Titrations were performed for the compounds ( 1 $5 \mu \mathrm{M})$, and each compound was introduced into DNA solution $(50 \mu \mathrm{M})$ present in the viscometer. The CD spectra of DNA were recorded on a Jasco $\mathrm{J}-810$ spectropolarimeter at $25.0 \pm 0.1^{\circ} \mathrm{C}$. CT-DNA used were $200 \mu \mathrm{M}$ in concentration and compounds solutions was added to a ratio of $1: 1$ (DNA/ compound)

X-Ray Crystallography A suitable brown block-shaped single crystal with dimensions of $0.80 \times 0.40 \times 0.10 \mathrm{~mm}^{3}$ was mounted in a sealed tube for data collection which was performed on a Bruker AXS SMART CCD diffractometer equipped with a graphite-monochromatic $\mathrm{MoK} \alpha$ radiation $(\lambda=0.71073 \AA)$ at $223(2) \mathrm{K}$. Unit cell dimensions were obtained with leastsquares refinements, and all structures were solved by direct methods. The program SMART was used to collect the intensity data, ${ }^{12)}$ SAINT for integration of the intensity, ${ }^{18)}$ SADABS for absorption correction and SHELXTL for structure solution and refinements on $F^{2} .^{19,20)}$ The phenyl ring was disordered into two positions with occupancy ratio $63: 37$. There are lot of residual peaks which were too weak and could not be characterised. $\mathrm{H}$ atom of N3 was located from different map and refined with restraints in bond length and parameters. The $\mathrm{H}$ atoms of the solvent molecules were not located.

Synthesis of the Ligand and the Complex The ligand $\mathrm{H}_{2} \mathrm{~L}$ was prepared as described previously. ${ }^{21)}$ In short, $\mathrm{H}_{2} \mathrm{~L}$ was obtained by the condensation of 2-acetylpyridine and isophthalic hydrozide in ethanol solution with the addition of several drops of conc. HCl. The Ni(II) complex $\mathbf{1}$, $\left[\mathrm{Ni}_{4}(\mathrm{HL})_{4}\right]\left(\mathrm{ClO}_{4}\right)_{4} \cdot 4 \mathrm{H}_{2} \mathrm{O} \cdot 0.5 \mathrm{CH}_{3} \mathrm{OH}$, was prepared by the reaction of $\mathrm{Ni}\left(\mathrm{ClO}_{4}\right)_{2} \cdot 6 \mathrm{H}_{2} \mathrm{O}$ and $\mathrm{H}_{2} \mathrm{~L}$. To a solution of $\mathrm{H}_{2} \mathrm{~L}(0.2 \mathrm{~g}, 0.5 \mathrm{mmol})$ in $5 \mathrm{ml}$ $\mathrm{CH}_{3} \mathrm{OH}$ and $5 \mathrm{ml} \mathrm{CHCl}$. was added a solution of $\mathrm{Ni}\left(\mathrm{ClO}_{4}\right)_{2} \cdot 6 \mathrm{H}_{2} \mathrm{O}(0.18 \mathrm{~g}$, $0.5 \mathrm{mmol}$ ) in $5 \mathrm{ml} \mathrm{CH} \mathrm{CH}_{3} \mathrm{OH}$. This reaction mixture was stirred for $1 \mathrm{~h}$, a brown precipitate was filtered off and washed with cold methanol. Yield: $0.23 \mathrm{~g}$ (60.2 \%). Anal. Calcd for $\mathrm{C}_{85.5} \mathrm{H}_{86} \mathrm{Cl}_{4} \mathrm{Ni}_{4} \mathrm{~N}_{24} \mathrm{O}_{28.5}: \mathrm{C}, 44.85 ; \mathrm{H}, 3.74 ; \mathrm{N}$, 14.50. Found: $\mathrm{C}, 44.52 ; \mathrm{H}, 3.56 ; \mathrm{N}, 14.68$. Brown single crystals of complex 1 suitable for X-ray study was obtained by slow evaporation of the mother solution. The complex is soluble at room temperature in methanol, DMF and dimethyl sulfoxide (DMSO).

Superoxide Radical Scavenging Assay The superoxide radicals $\left(\mathrm{O}_{2}^{-*}\right)$ were generated in vitro by non-enzymatic system and determined spectrophotometrically by NBT photoreduction method with a little modification in the method adopted elsewhere. ${ }^{22)}$ The tested compounds were dissolved in DMF. The assay mixture, in a total volume of $5 \mathrm{ml}$, contained MET (10 mM), NBT $(46 \mu \mathrm{M}), \operatorname{VitB}_{2}(3.3 \mu \mathrm{M})$, the tested compound $(5-30 \mu \mathrm{M})$ and a phosphate buffer $(67 \mathrm{~mm}, \mathrm{pH} 7.8)$. After illuminating with a fluorescent lamp at $30{ }^{\circ} \mathrm{C}$ for $10 \mathrm{~min}$, the absorbance of the samples $\left(A_{\mathrm{i}}\right)$ was measured at $560 \mathrm{~nm}$. The suppression ratio for $\mathrm{O}_{2}^{-\cdot}$ was calculated from the following expression:

$$
\text { suppression ratio }(\%)=A_{0}-A_{\mathrm{i}} / A_{0} \times 100
$$

Drug activity was expressed as the $50 \%$ inhibitory concentration $\left(\mathrm{IC}_{50}\right) . \mathrm{IC}_{50}$ values were calculated from regression lines where: $x$ was the tested compound concentration in $\mathrm{mm}$ and $y$ was percent inhibition of the tested compounds.

Hydroxyl Radical Scavenging Assay The hydroxyl radicals $\left(\mathrm{OH}^{\circ}\right)$ in aqueous media were generated through the Fenton system. ${ }^{23)}$ The solution of the tested compound was prepared with DMF. The $5 \mathrm{ml}$ assay mixture con- tained following reagents: safranin $(11.4 \mu \mathrm{M})$, ethylenediaminetetraacetic acid (EDTA)-Fe(II) $(40 \mu \mathrm{M}), \mathrm{H}_{2} \mathrm{O}_{2}(1.76 \mathrm{~mm})$, the tested compound (5$30 \mu \mathrm{M})$ and a phosphate buffer $(67 \mathrm{~mm}, \mathrm{pH} 7.4)$. The assay mixtures were incubated at $37^{\circ} \mathrm{C}$ for $30 \mathrm{~min}$ in a water bath. After which, the absorbance was measured at $520 \mathrm{~nm}$. All the tests were run in triplicate and expressed as the mean \pm standard deviation (S.D.). The suppression ratio for $\mathrm{OH}^{*}$ was calculated from the following expression:

$$
\text { suppression ratio }(\%)=\left[\left(A_{\mathrm{i}}-A_{0}\right) /\left(A_{\mathrm{c}}-A_{0}\right)\right] \times 100
$$

(Where $A_{\mathrm{i}}=$ the absorbance in the presence of the tested compound; $A_{0}=$ the absorbance in the absence of the tested compound; $A_{\mathrm{c}}=$ the absorbance in the absence of the tested compound, EDTA-Fe (II), $\mathrm{H}_{2} \mathrm{O}_{2}$.)

Acknowledgements This work was supported by the Fundamental Research Funds for the Central Universities and the Ministry of Education, Singapore through NUS (FRC Grant No. R143-000-371-112 ).

\section{References}

1) Kelland L. R., Eur. J. Cancer, 41, 971-979 (2005)

2) Hackl E. V., Galkin V. L., Blagoi Y. P., Int. J. Biol. Macromol., 34, 303-308 (2004).

3) Jiao K., Wang Q. X., Sun W., Jian F. F., J. Inorg. Biochem., 99, 13691375 (2005).

4) Rajaram R., Nair R. U., Ramasami T., Biochem. Biophys. Res. Commun., 210, 434-440 (1995).

5) Vijavalakshmi R., Kanthimathi M., Subramanian V., Nair B. U., Biochim. Biophys. Acta, 1475, 157-162 (2000).

6) Savanini L., Chiasserini L., Gaeta A., Pellerano C., Bioorg. Med. Chem., 10, 2193-2195 (2002).

7) Dilworth J. R., Coord. Chem. Rev., 21, 29-62 (1976).

8) Merchant J. R., Clothia D. S., J. Med. Chem., 13, 335-336 (1970)

9) Biradar N. S., Havinale B. R., Inorg. Chim. Acta, 17, 157-160 (1979).

10) Halcrow M. A., Christou G., Chem. Rev., 94, $2421-2481$ (1994).

11) Kelly J. M., Murphy M. J., Mcconnell D. J., Ohuigin C., Nucleic Acids Res., 13, 167-184 (1985).

12) Mudasir, Yoshioka N., Inoue H., J. Inorg. Biochem., 77, 239-247 (1999).

13) Bisceglie F., Baldini M., Belicchi-Ferrari M., Buluggiu E., Careri M., Pelosi G., Pinelli S., Tarasconi P., Eur. J. Med. Chem., 42, 627-634 (2007).

14) Efink M. R., Ghiron C. A., Anal. Biochem., 114, 199-227 (1981).

15) Wang X. L., Chao H., Li H., Hong X. L., Liu Y. J., Tan L. F., Ji L. N., J. Inorg. Biochem., 98, 1143-1150 (2004).

16) Samuni A., Krisna M. C., "Handbook of Synthetic Antioxidants," ed. by Packer L., Cadenas E., Marcel Dekker, New York, 1997, pp. 351373 .

17) Wang B. D., Yang Z. Y., Crewdson P., Wang D. Q., J. Inorg. Biochem., 101, 1492-1504 (2007)

18) SMART and SAINT Software Reference Manuals, Versions 5.6 and 6.4, Bruker AXS, Madison, 2003.

19) Sheldrick, GM SADABS (2003) Software for Empirical Absorption Correction, University of Göttingen, Germany.

20) SHELXTL Reference Manual, Version 6.14, Siemens Energy \& Automation, Analytical Instrumentation, Madison, 2003.

21) He Z., He C., Wang Z. M., Gao E. Q., Liu Y., Yan C. H., Dalton Trans., 4, 502-504 (2004).

22) Li T. R., Yang Z. Y, Wang B. D., Chem. Pharm. Bull., 55, 26-28 (2007).

23) Winterbourn C. C., Biochem. J., 198, 125-131 (1981). 